\title{
An end to Nordic exceptionalism? Europeanisation and Nordic development policies
}

\section{Ole Elgström \& Sarah Delputte}

To cite this article: Ole Elgström \& Sarah Delputte (2015): An end to Nordic exceptionalism? Europeanisation and Nordic development policies, European Politics and Society, DOI: 10.1080/23745118.2015.1075765

To link to this article: http://dx.doi.org/10.1080/23745118.2015.1075765

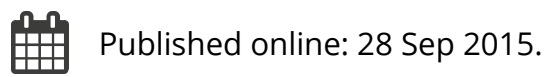

[كubmit your article to this journal ๘

щ Article views: 17

Q View related articles $\sqsubset$

View Crossmark data ¿

Citing articles: 1 View citing articles $\longleftarrow$ 


\title{
An end to Nordic exceptionalism? Europeanisation and Nordic development policies
}

\author{
Ole Elgström ${ }^{a}$ and Sarah Delputte ${ }^{b}$ \\ ${ }^{a}$ Department of Political Science, Lund University, Sweden; ${ }^{b}$ Centre for EU Studies, Ghent University, Belgium
}

\begin{abstract}
The Nordic countries have traditionally been praised for their generous and advanced development policies. Recently, however, it has been claimed that the Nordic model has faded: that the Nordic donors have become more similar to other European donors. One possible reason for such trends is influences from EU policies, that is, Europeanisation. This article critically evaluates such claims by presenting arguments for and against Europeanisation effects. We argue that changes have indeed taken place. The Nordic exceptionalism has been eroded. At the same time, a convergence of European aid policies has occurred. The question is if this is the consequence of Europeanisation - or is it rather a result of Nordicisation (the Nordic countries influencing the EU), or perhaps like-mindisation (a broader set of progressive member states having impact upon EU policies)? We suggest that Europeanisation has been extremely weak while there is strong evidence of Nordicisation but also, and increasingly, of like-mindisation. Today, a core group of mainly northern member states, including the Nordics, are the main driving forces behind European aid convergence.
\end{abstract}

\section{KEYWORDS}

EU development policy; Europeanisation; likemindisation; Nordic donors; Nordicisation

\section{Introduction}

The Nordic countries - here referring to Denmark, Finland, Norway and Sweden ${ }^{1}$ - have traditionally been praised for their generous and advanced development policies. The 'Nordic model' has, for instance, included a large share of multilateral assistance, a focus on low-income countries, and a large portion of grant aid. It has also placed significant emphasis on democracy, gender, environment and human right (Pratt, 1989; Stokke, 1989; Selbervik with Nygaard, 2006). In recent years, this idyllic picture has been challenged. It has been claimed that the Nordic model has faded and that Nordic donors have become more similar to other European donors, but also that their development policies have taken off in different directions, at least to a certain extent and in some respects (Odén, 2011; Olsen, 2013). One possible reason for such trends is pressure or indirect influence from the European Union (EU). This article critically evaluates such claims by presenting arguments for and against Europeanisation effects. In doing so, it makes a distinction between four aspects of development policy: structures, values and norms, instruments and practices. 
We argue that changes have indeed taken place. The Nordic exceptionalism that existed up until the 1990s has been eroded, though still visible in certain areas, and the foreign aid of individual Nordic countries has to a certain extent diverged in their emphases and foci. At the same time, a convergence of European aid policies has occurred. The question is if these changes are the consequence of Europeanisation (i.e. the EU influencing member states), or whether they rather are a result of Nordicisation (i.e. the Nordic countries influencing the EU but also other member states), or perhaps like-mindisation (i.e. a broader set of progressive member states impacting upon EU policies). We suggest that in the case of the Nordic states, Europeanisation has been extremely weak. We also argue that strong Nordic attitudes of superiority ('what have we to learn from the EU?') and strong identities as 'good donors' have obstructed Europeanisation and fostered a feeling that it is the Nordics that have influenced the EU, and not vice versa. On the other hand, there is strong evidence of Nordicisation but also, and increasingly, of 'like-mindisation'. Today, a core group of like-minded countries, including the Nordics, are the main driving forces behind European aid convergence.

The article starts with a brief discussion of how it relates to the conceptual framework presented by Orbie and Carbone (2015) in the introduction to this volume, followed by a short section on methods and sources of evidence. Then, it briefly recapitulates the main elements of the 'Nordic model'. The empirical section analyses the degree of erosion of this model, specifying on what levels and to what extent change has actually taken place. The next section concentrates on the cause(s) of change, asking whether it is a result of Europeanisation, or rather a consequence of Nordicisation or 'like-mindisation'. Finally, the conclusion looks at the reasons behind the lack of Europeanisation in the Nordic case and discusses future trends and developments.

\section{Conceptual issues and methodological considerations}

Following Orbie and Carbone (2015), Europeanisation is seen here primarily as a top-down phenomenon, where elements of EU policies are adopted by EU member states. We will, however, also refer to policy transfers in the opposite direction (i.e. bottom-up Europeanisation), as it is in the Nordic debate often taken for granted that ideas of Nordic foreign aid have more often influenced the EU than vice versa, and also influence going from some EU member states to others (i.e. horizontal Europeanisation). While Orbie and Carbone (2015) distinguish between Europeanisation of policy, polity and politics, our focus will mainly be on policies, which refer to 'instruments, objectives and discourses in a specific domain', though we will also briefly discuss institutional changes.

It is also fruitful to make further distinctions within the broad category of 'policy'. Our motive for this is the empirical observation that EU may impact upon some aspects of policy, while hardly affecting others at all. Europeanisation may thus be uneven and patchy, depending on what aspect of development policy we look at. Against this background, we differentiate between (potential) effects on structures, values and norms, instruments and practices of foreign aid. Structures in this context concern the volume of aid and selection of recipients. Values and norms refer to the overarching objectives of foreign development policy and the priorities made between them, and are primarily revealed by discursive practices. It is here important both to scrutinise development policies in a broad sense and foreign aid policy more specifically. Instruments imply the major 
modes of giving aid, including choices between project aid, budget support, and aid via Non-Governmental Organisations (NGOs). Practices, finally, indicate what donors do on the ground, how their offices in developing countries work in order to carry out their missions, including patterns of co-ordination.

As pointed out by Orbie and Carbone (2015), it is remarkably difficult to pinpoint the existence and extent of Europeanisation. In the case of the Nordic countries, these have for a long time had well-defined policies and practices, situated in well-developed institutional settings. They have by many been considered to be at the forefront of development policy with generous and altruistic programmes. The EU's development agenda has often been considered as less advanced, being a compromise between groups of member states with various backgrounds and interests. For this reason, one would hardly expect to find much of EU influences on Nordic development policies: any such influences would be expected to have occurred in recent years. To determine Europeanisation, EU policy change must precede domestic change. We must also be able to discern a logical chain or mechanism between the two changes.

This article relies on existing scholarly sources, official documents and reports such as the peer reviews of the Development Assistance Committee (DAC), and qualitative semistructured interviews with Nordic aid officials. We connect to a discourse on Nordic internationalism, which subscribes to the idea of Nordic exceptionalism and argues that the Nordics have acted, and are perhaps still acting, as norm entrepreneurs on the global arena (Lawler, 1997, 2007; Ingebritsen, 2002; Browning, 2007). There are number of detailed descriptions and analyses of the traditional Nordic model, but also of changes in policy and practises. Some of the latter concern aid policy specifically (Selbervik with Nygaard, 2006; Development Today, 2010; Odén, 2011), others discuss Nordic Africa policies and development policy more generally (Olsen, 2011, 2013) and still others only Swedish aid policy change (Odén \& Wohlgemuth, 2006). None of these studies have, however, been primarily guided by a Europeanisation perspective. Many of these sources are based on interviews with large numbers of aid practitioners in the Nordic countries and therefore rest on solid empirical data. We have complemented this material with interviews with officials working at headquarters' level and in aid agencies in the field. More specifically, four interviews were conducted by telephone with Swedish officials intimately involved in EU-Swedish aid relations, of which two in Stockholm and two in Brussels. The analysis on aid practices is based on nine semi-structured interviews carried out in 2011 and 2012 in Dar-es-Salaam (Tanzania) and Lusaka (Zambia) with officials representing Denmark, Finland and Sweden.

\section{The traditional Nordic aid model}

Nordic experts on development policy agree on the existence in the 1970s, 1980s and 1990s of a 'Nordic aid model' (Development Today, 2010; Odén, 2011) and of 'Nordic exceptionalism' (Selbervik with Nygaard, 2006; Olsen, 2013). Denmark, Finland, Norway and Sweden stood out as generous donors, driven by solidarity, altruism, moral and humanitarian concerns, rather than material interests. While there were, and are, certainly differences between these countries - with Finland often seen as the 'odd man out' in terms of less generosity, and with Denmark and Finland demonstrating more aid tied to domestic interests - we will treat them as one group. 
The Nordic uniqueness in development policy should be seen in the light of a broader discourse on the Nordics as value-driven 'norm entrepreneurs' (Lawler, 1997, 2007; Ingebritsen, 2002; Olsen, 2013), 'humane internationalists' (Pratt, 1989; Stokke, 1989), trying to spread the norms they cherish to other actors, by persuasion and by acting as role models. Foreign assistance is usually considered a key instrument in these efforts, but references are also made to, for example, environmental policy and conflict resolution.

The Nordic states have for decades provided more assistance to developing countries than the DAC average. Their aid levels have generally been above 0.7 per cent of GNI (Gross National Income) while the DAC average has been between 0.2 and 0.4 per cent (Selbervik with Nygaard, 2006; Delputte et al., 2015). Moreover, foreign aid has been mainly given as grants and has had a strong focus on low-income countries: for instance, in the 1990s, Sweden, Norway and Denmark allocated on average 50 per cent, or more, of their bilateral aid to sub-Saharan Africa (Selbervik with Nygaard, 2006). Nordic foreign assistance has traditionally featured a strong poverty orientation and a focus on social infrastructure and welfare. Much aid has thus been distributed to health, education, water and sanitation. Another strong focus has been on good governance, especially since the 1990s, and on women's rights (Selbervik with Nygaard, 2006; Development Today, 2010). Nordic donors have also demonstrated a stronger support for multilateralism, and not least for the UN aid system, than other donors (Odén, 2011). Denmark and Norway, for example, for many years had a policy indicating a 50-50 split between bilateral and multilateral aid (Selbervik with Nygaard, 2006). The Nordic countries have favoured a distinction between aid and export funding and have, at least up to the mid-1980s, expressed a critical distance from the policies of the International Financial Institutions (Odén, 2011). In principle, if not always in practice, there has been a strong emphasis on recipient ownership, conceiving development relations as partnership (Odén \& Wohlgemuth, 2006).

We can thus clearly distinguish a traditional Nordic aid model, despite the differences that exist between the countries. In the next section, we turn to the question whether this Nordic exceptionalism is still there. To what extent have changes taken place in the Nordic model, how far-reaching are these changes, and do they concern all aspects of development policy or just a few of them?

\section{Changes in Nordic development policies}

In brief, the Nordic donors are still different compared to most other donors - but much less so than 20 years ago. Two important caveats are in order. First and foremost, the Nordics are today not the only countries within the EU with such progressive policies, and not necessarily the most important ones. References are often made to the 'likeminded countries' or to the 'Nordic Plus' donors (including also the Netherlands, the United Kingdom and Ireland), both at headquarter level and in the field (Selbervik with Nygaard, 2006; Olsen, 2013; Interviews 1, 2, 4, 5, 6, 8). In some areas, the UK, for example, may be more progressive than the Nordic group. Also at the level of aid practices, the 'Nordic Plus' donors have played a distinctive role in implementing the international aid effectiveness principles - not the least in countries like Tanzania and Zambia, which have been considered successful examples of recipient-led efforts to manage relations 
with donors. This belonging to a larger club obviously diminishes the exceptionalism of the Nordic countries.

Second, the differences between the four Nordics seem to have grown. According to Olsen (2013, p. 421), 'the traditional Nordic aid cooperation has faltered somewhat... cooperation with the other Nordics is no longer a priority'. Norway, being outside the EU (though still often following EU policies), is claimed to have 'become a lonely player' (Development Today, 2010, p. 5) or a 'free-wheeler' (Odén, 2011, p. 48), giving Oslo a higher degree of freedom of action, but also less chance to influence the policies of the EU. Within the European Union, the Nordics do not any longer necessarily form the ideological core and may prefer to work in other constellations within the framework of the like-minded countries. Recently, references have been made to 'the Nordic Plus Plus', varying from issue-area to issue-area but often including also France and Germany and sometimes Poland and Spain (Interviews 1, 4). This indicates a spread of Nordic aid ideology to a larger group of countries - thereby increasing its political weight considerably. In development circles in Brussels as well as in the field, references are increasingly made to the 'like-minded countries' than to 'the Nordics' (Interviews 4, 5).

When turning to an analysis of the aspects of development policy defined above, we see a diverse and somewhat heterogeneous picture. Still, the general picture is one of very limited Europeanisation. On the structural level, the aid budgets of the Nordics are still well above the DAC average. Despite economic and budgetary difficulties - admittedly of a lesser magnitude than in most other EU donors - they have kept up their levels of foreign assistance. While Denmark, Sweden and Norway continue to provide far more than 0.7 per cent Official Development Assistance (ODA)/GNI, Finland has also stepped up its aid efforts and remains committed to reaching the internationally agreed aid target by 2015 (OECD-DAC, 2014; Ministry of Foreign Affairs of Finland, 2014). They all still give more than others to multilateral institutions, between 25 and 30 per cent of their total aid, and large quantities (around 60 per cent of their total aid) to LDCs, with contributions to sub-Saharan Africa accounting for in between 40 and 50 per cent (OECD-DAC, 2011, 2012, 2013a, 2013b).

The underlying motive for giving foreign assistance has remained virtually the same during 60 years of aid giving. Founded in domestic principles and given the lack of colonial history, international solidarity became the cornerstone of Nordic assistance programmes already from the beginning (Odén \& Wohlgemuth, 2006). Furthermore, the main aid objectives have also remained approximately the same. In the Swedish case, a government bill of 1962 laid the foundations for the country's aid policy and its principles have continued to guide Swedish assistance over the years to a surprising extent. The fight against poverty has always been the overarching goal, while economic growth, equal distribution of resources and a support for recipient states' responsibility for their own development were basic elements of Swedish policy, later complemented by environmental concerns and gender equality as additional objectives (Odén \& Wohlgemuth, 2006). Poverty reduction also remains the overarching goal of Danish development cooperation, after it was established as a central objective in the 1971 Act on International Development Co-operation. Issues like the environment, gender equality and human rights have been added as important elements in the 1980s (OECD-DAC, 2011; Ministry of Foreign Affairs of Denmark, 2014). Norwegian and Finnish development policies also show continuity 
when it comes to focussing on the primary objectives of poverty reduction and sustainable development (OECD-DAC, 2012, 2013b).

In recent years, priorities have, however, changed, at least to a certain extent. More emphasis has been put on the importance of the private sector for economic growth, as well as on the perceived necessity to integrate poorer countries into the global economy (Odén, 2011). We can thus witness a greater attention to 'the market' as a mover of prosperity and development, and consequently relative less focus on 'the state' as the main force behind development - a clear change compared to the 1970s and 1980s (cf. Harman \& Williams, 2014). This evolution also involves a greater emphasis on the expansion of Nordic countries' business and investments in developing countries (OECD-DAC, 2011, 2012, 2013a, 2013b). Another development is the increasing attention to good governance and human rights (Odén, 2011), a theme that has been visible from the beginning but has more and more been made a centrepiece of Nordic development strategies. Next, development policies have come to prioritise policy coherence for development (Stochetti, 2013). This was an insight that came from the realisation that sector policies sometimes contradicted each other and that development concerns often came out as losers when competing with commercial or security interests. Nordic donors have introduced mechanisms and policy processes to guarantee that all relevant policy areas - be it trade policy, agricultural policy, security policy or migration policy - work for the same goal: sustainable development.

However, while its importance has been increasingly emphasised, not least as a result of Swedish government policy initiatives (Odén, 2011; Interview 1), the fact that different political and administrative institutions are in charge of different sector policies makes policy coherence a daunting challenge. For example, although Norway has established formal and informal mechanisms for inter-ministerial co-ordination and policy arbitration, actual efforts remain issue-specific and ad hoc (OECD-DAC, 2013b). Moroever, when looking at development policy in a broad sense, links between development and security concerns have been increasingly put into focus. Besides changes in discourse in this direction, Nordic countries have allocated more assistance to conflict areas, but where EU forces have been involved as peacekeepers (cf. Development Today, 2010; Olsen, 2013).

Considering aid modalities and policy instruments, it can first be noted that sector allocations have shifted, following international trends (Odén \& Wohlgemuth, 2006). While health, education, infrastructural and rural development projects have always been present in aid programmes, we have since the Millennium seen a growing emphasis on new policy fields, including support for conflict prevention, democracy and private business initiatives. Nordic donors' development strategies show a clear commitment to align their aid with partner countries' national priorities and make use of their institutions and systems. A trend towards programme-based approaches, associated with the belief in the virtue of recipient country ownership, is clearly visible. They have provided more budget support than the OECD-DAC average - especially in countries like Tanzania, Zambia or Mozambique, where substantial shares of their budgets have been provided through the state (OECD-DAC, 2011, 2012, 2013a, 2013b). However, in recent years, this picture has changed as the use of budget support has decreased and a shift in focus is taking place from general to sector budget support. In 2010, Denmark was the only Nordic donor that reached the target of providing 66 per cent of aid flows in the form of programme-based approaches (OECD, 2011). 
Regarding the actual implementation of aid policy on the ground, there is little evidence of major change due to EU co-ordination efforts (Delputte \& Orbie, 2014; see also Carbone, 2013). Aid implementation being highly decentralised in the Nordic states (Selbervik with Nygaard, 2006), these countries' development offices and embassies in developing countries have become sites of considerable expertise. This is obviously one factor that has spoken against increased co-ordination within the framework of the EU. Co-ordination, when existing, has been with the other Nordic donors, or - in recent years - increasingly with other like-minded countries (within the 'Nordic Plus' framework) (Interview 4; Odén, 2011; Olsen, 2011). In those countries that have been considered 'best practices' in the implementation of the aid effectiveness agenda, important steps towards aid co-ordination were initiated by Nordic countries already at the end of the 1990s, in close cooperation with the government and other like-minded donors. Hence, at the time the EU's policy framework on aid effectiveness was adopted, aid co-ordination based on Joint Assistance Strategies was already far advanced. Our interviews show that the EU's co-ordinator role in Tanzania and Zambia is rather limited (Interviews 5, 6, $11,12)$. For Nordic donors, the EU does not offer much added value to the existing formal and informal coordination processes (Interview 5, 6, 7, 11, 13). Not only because non-EU like-minded donors such as Norway are excluded, but also because EU coordination is perceived as being driven by EU visibility considerations rather than by a concern to improve aid delivery (Interview 10).

To summarise, while changes, although not drastic, can be detected in Nordic policy objectives and instruments during the time period after the Danish, Finnish and Swedish accessions to the EU in 1995, no such traces are visible either in the structural aspects discussed above, or on the ground. The changes that we have observed rather consist of additional elements to an existing structure of goals and instruments than of shifts in essential features of policy. In the next section, we will discuss if the changes that have taken place may be interpreted as signs of ongoing Europeanisation processes.

\section{Europeanisation, Nordicisation or like-mindisation?}

Above, we have identified a number of elements that have been introduced into Nordic development policy during the last two decades or so. Similar conclusions, pointing in the direction of a noticeable but still limited erosion of the Nordic aid model, are drawn in existing literature. Some of these publications furthermore argue that we can see a clear ongoing convergence of European development policies (Carbone, 2007; Olsen, 2013; Zemanová, 2012). The policies of the EU itself have undergone continuous changes. Many EU member states have, more or less thoroughly, carried out reforms of their policies, often resulting in policies and strategies that are more similar to traditional Nordic aid practices than before. We have already underlined the emergence of a 'Nordic Plus' constellation of 'like-minded countries', including the UK, Ireland and the Netherlands besides the Nordics and the more recent emergence of a 'Nordic Plus Plus' coalition. Such groups of countries with progressive ideas, differing across issue-areas, today exert considerable influence on EU policy (cf. Olsen, 2013, p. 421). Other long-standing members have also introduced novel elements into their aid arsenal, while newer member states in eastern and southern Europe have created entirely new structures and policies after their accession to the Union (Zemanová, 2012; Lightfoot \& Szent-Ivanyi, 2014). The 
result has arguably been an EU where both member state policies and EU policy have converged, and now demonstrate many more similar traits and features than ever before. According to one interviewee, the EU is today 'very much speaking with one voice' in aid policy (Interview 1). Another interviewee described the existence of a 'European consensus', where actors are in agreement on 98 per cent of all policies (Interview 2). This convergence is mirrored in the new 'Agenda for Change' policy of 2012 (Interview 4).

The question then is if the changes in Nordic development policies and the tendencies described above are the consequence of Europeanisation, of Nordicisation, or of 'likemindisation' (the 'Nordic Plus' having had similar influences). Evidence of a Europeanisation of Nordic policies is very hard to find, although 'non-governmental sources' are reported to have stressed that 'the general trend in Swedish EU policy since 1995 has been one of adjustment to the EU and to its policies' (Olsen, 2013, p. 415). Brommesson (2010, p. 228; on Europeanisation of Nordic security policies, see Rieker, 2004) introduced the concept of 'normative Europeanization', referring to 'a top-down process based on the logic of appropriateness, where states with a close relationship to the EU, i.e. candidate and member states, develop a commitment to a European centre ... and their normative point of departure is changed'. A European loyalty becomes the point of reference, rather than national loyalty. According to Brommesson (2010), tendencies of normative Europeanisation of Swedish foreign policy can be detected. Is the same true for development policy? The Nordic states are in general well known for their propensity to follow and implement EU directives (Falkner \& Treib, 2008), and this could speak in favour of an inclusion of EU values in this policy area, too. However, the Nordics have been extremely proud of their aid record and their aid policies, which have generally (and not only in the North) been considered progressive and at the forefront of international discourses. Mirroring this image, there seems to have been a tendency in aid circles (notably in aid agencies and within the NGO community), especially when the Nordics became EU members in 1995, to regard EU foreign assistance as much less advanced and much less progressive. The idea that 'we have something to learn from the EU' appears to have been far-fetched for many Nordic politicians and practitioners (Interviews 1, 4). EU aid was considered 'outmoded' and its aid structures were considered frustratingly bureaucratic and ineffective (Interview 1). These bureaucratic constraints also constitute a factor in Nordic donors' perceptions of EU delegations in the field. In Tanzania and Zambia, the EU's complex aid bureaucracy and lack of flexibility was fiercely criticised as it results in decisions and initiatives that are not always aligned to the local situation (Interviews $6,8,11)$. Some Nordic officials raised the idea that in some respects the EU 'could learn from some of the member states', and not the least from the Nordic (plus) donors (Interviews 6, 8). The Nordic self-image is in strong contrast with these perceptions of the EU: 'we just have different ways of looking at things, we trust people much more because we're not working on perverse incentives, we are actually working on the right incentives to try to achieve the greater good' (Interview 6). From this perspective, increased EU coordination would mean that they 'would have to compromise', which 'would have a negative impact on [their] joint positions' (Interview 5). Such attitudes obviously speak against any impact of ideas stemming from the EU.

Our focus on strong Nordic identities (as 'best in class, advanced aid donors') and on the long traditions of giving generous aid according to a 'Nordic model' as key explanatory factors behind the absence of Europeanisation is theoretically closely linked to sociological 
and historical institutionalism. Sociological institutionalism is interested in the capacity of cultural and organisational practices (institutions) to mould the preferences and interests of actors (Rosamond, 2000). People act according to a logic of appropriateness, 'taking cues from their institutional environment as they construct their preferences' (Pollack, 2009, p. 127). Policies are thus shaped by institutional and national identities. Historical institutionalism focuses on the effects of institutions over time. Institutional choices taken in the past tend to persist, thereby shaping and constraining actors later in time. Actors are loath to abandon existing policies, adapting them only incrementally to changes in the environment (Pollack, 2009). Both theories may help to explain the tendency among Nordic aid bureaucrats and politicians to stick with existing institutions and policies and to be sceptical to external ideas.

Attitudes may, however, have changed gradually over the years. One of our interviewees thus argued that Nordic aid officials today are much more open to ideational influences from other EU actors and more sympathetic to other countries' 'ideological hobbyhorses' (Interview 2). To the extent that this is the case, this may be evidence of a growing feeling of 'EU solidarity' as a result of an ongoing socialisation process. Representatives from the like-minded countries are in contact frequently and 'active orchestration' takes place in Council working groups (Interview 4). Such socialisation processes, arguably a result of 'normative suasion' (Lewis, 2005), have been observed elsewhere in everyday decision making in the EU, for example in COREPER where Lewis (2005, p. 937) found an 'adherence to a set of norm-guided rules and principled beliefs in collectively legitimating arguments and making decisions' and where 'the stamp of collectively negotiated standards of appropriateness is unmistakable' (Lewis, 2005, p. 952). Also at the field level, informal coordination with like-minded donors such as the UK and the Netherlands takes place on a regularly basis (Interviews 5, 9).

Empirically, there might arguably be influences from the EU's long-standing focus on market forces and the importance of private business in its development policy, as expressed for example in the Lomé Convention with the African, Caribbean and Pacific group of countries. Certainly, there has been an increasing emphasis on these aspects in Nordic aid recently, appearing well after such elements appeared in EU policy. On the other hand, there are also international trends here to reckon with, which point in exactly the same direction (Fejerskov, 2013). A totally transformed aid landscape, with many more financial flows to take note of and a diminished role for governmental assistance, had created a situation where private actors 'had to be taken into account' (Interview 1). ${ }^{2}$ Another potential area of Europeanisation is the increasing securitisation of foreign aid. For example, we have recently witnessed more Nordic assistance going to countries where the Nordic states are involved in peace-keeping missions. However, the links between security and development have not only been underlined in EU discourses, but also in international discourse in general, especially since the events of $9 / 11$. Evidence of normative Europeanisation is very limited - and inconclusive as these shifts in ideational priorities may also have resulted from international ideological currents.

Is there then any more solid evidence of a Nordicisation of EU policies? Browning (2007, p. 44) argues that internationalist and solidarist elements of Nordic foreign policy have become part of the EU's international profile, and sees this as a 'success for Nordic ideals and the Nordic model'. In official documents on foreign aid, the Nordics have stressed the importance, and the possibility, of influencing EU policies towards Africa 
(Odén, 2011, p. 39). Aid practitioners uniformly discard the notion that EU policies should have had any significant influence on Nordic aid policies, and instead pay tribute to the beneficial effects of Nordic influence on EU norms and values (Interviews 1, 3, 4). Gender equality, increased transparency and a stronger focus on poverty eradication are often cited examples of Nordic ideational influence (Interviews 1, 2, 3, 4). Such norm transfers may take place in many settings. Gender issues are thus regularly brought to the fore by Nordic delegates in all situations and in all groupings having to do with aid (Interview 3). Not least important is the normative suasion that takes place in expert groups where officials from more 'advanced' member states teach 'correct' norms to their colleagues. Examples include the linking of human rights and democracy concerns to budget aid allocation (Interviews 1,4) and the spreading of gender norms. In the latter field, the European Commission in the early 2000s had little expertise, giving much leeway for Nordic delegates to propagate their ideals and to exert influence through expert committees (Elgström, 2000).

Olsen (2013) has investigated the possibility of Nordicisation in a recent article, with a focus on the EU's Africa policy. Referring to an analysis of five separate cases involving policies towards Africa, he finds that the case of policies towards Zimbabwe 'may show it is possible for small Nordic countries to influence the Africa policy of the European Union' (Olsen, 2013, p. 415). Likewise, the 2005 European Consensus on Development 'may be interpreted as an illustration of Nordicisation', as the Nordics initiated the debate on European aid harmonisation and coherence and suggested the content of the policies that ensued (cf. Odén, 2011, p. 30; Olsen, 2013, p. 420). The Nordic countries thus arguably demonstrated agenda-setting power in this instance.

However, Olsen (2013, p. 420) adds that in both cases the Nordic states worked in close co-operation with a number of like-minded countries. Thus, 'Denmark, Sweden and Norway have close and positive working relationships with the UK, the Netherlands and Ireland on the issues of aid harmonisation and in particular on the improvement of the delivery of development aid'. Arguably, the origins of the EU's aid effectiveness framework, which is guided by the principle of complementarity and elaborated in the Code of Conduct on Complementarity and Division of Labour (2007), can be found in the 'Nordic Plus' Complementarity Principles (2005) which inspired the Joint Assistance Strategy processes in the field. One interviewee gave the growing importance placed on 'soft values' in EU discourse and policy, clearly expressed in the 2012 'Agenda for Change', as another example of like-minded country influence (Interview 1). These examples can thus be interpreted as illustrations of 'like-mindisation', with a coalition of ideologically similar, progressive countries working in tandem to influence EU policies, rather than as proofs of Nordicisation per se. Our conclusion is that we witness a process where a broader group of progressive member states are increasingly becoming the driving forces behind European aid convergence. Nordicisation as such is giving way to 'like-mindisation'. One or several of the Nordic countries are still often key players but in various combinations with other member states. At the same time, there may be a 'melding of the Nordic brand of internationalism with Western/European internationalist approaches' (Browning, 2007, p. 45).

The role of the Nordics in the ongoing process of 'like-mindisation' is an intriguing question as it is linked to the debate on norm diffusion within the EU. It may be that the Nordic countries, or some of them, have acted as norm entrepreneurs within the EU, changing the priorities, positions and perhaps even values of fellow member states - as claimed by de 
Felice (2015) in this volume. In a survey of 249 state representatives in Council working groups, Sweden was ranked number four and Denmark number seven of all EU members in having the potential to influence the positions of other member states (Naurin, 2015), indicating that there is indeed a possibility for norm diffusion. There are, however, also other possibilities: policies may change as the result of domestic political changes (a new government with different aid ideology taking power) and governments may of course also be inspired by ideational signals from international actors, outside the EU.

\section{Summary and a concluding discussion on future trends}

In this article, we have investigated the impact of Europeanisation - if any - on Nordic development and aid policies. Our main finding is that such influences have been very limited. Some aspects of policy (larger aid flows and others structural characteristics, but also the specific character of aid practices on the ground) have not changed at all, or to a very limited extent, while we have witnessed additions to the set of aid objectives and instruments of the Nordic countries, indicating a limited degree of absorption of novel policy elements. These possible signs of Europeanisation can, however, better be explained by impulses from the global aid debate that have influenced the EU and the member states alike (cf. Harman \& Williams, 2014). It is well known that aid has its fads and fashions that are closely followed by most donors. During the last 15-20 years, the increasing emphasis placed on trade flows and on co-operation with the private sector in aid has resulted in a dramatically changed environment for traditional inter-governmental foreign assistance (Interviews 1,3,4). This development has arguably given rise to new debates and new trends in aid giving, further strengthening the overall importance of global transnational ideological influences.

We have also highlighted the convincing arguments for, and examples of, Nordicisation and, increasingly more important, of what we have called 'like-mindisation': the impact of an ideological core of progressive member states, which includes the Nordics but also some heavy players on the European stage, like the UK, the Netherlands and more recently also, in certain issue-areas, France and Germany. The result has been a convergence of European aid policies and practices. Nordic exceptionalism is still there - but much less visibly so than before the turn of the century.

How can the lack of Europeanisation be explained? The simple answer is that the Nordic countries already had well-developed foreign aid policies when they (excluding of course Norway) became EU members and that these policies were considered - not least, but not only, by politicians and practitioners in the Nordic countries - to be both more generous and more progressive than the existing EU aid policy. There was, consequently, no demand for ideational inputs from the EU level. The lack of ideational fit (cf. Lightfoot \& Szent-Ivanyi, 2014) that existed was by the Nordics seen as something that should be solved through normative changes in the EU, and not the other way round. Therefore the emphasis voiced in the Nordic countries on the opportunities for norm spread within the EU, that is, on potential Nordicisation. The attitude that 'we have nothing to learn from the EU' may still be there, but has been more and more replaced, as EU policy has gradually become more ambitious, by a feeling that 'we are all working within the EU with the same goal, to improve aid policy and practices, and we Nordics 
have something to contribute within this process' (Interviews 1,4). This could pave the way for joint efforts to improve aid practices, with the aim of making EU aid more effective.

Will we see more of Europeanisation in the years to come? On the structural level of policy, we can perhaps expect Europeanisation - but not concerning the Nordic member states. Their high aid budgets, and their focus on multilateral aid and grants, do not seem to be threatened and have withstood the economic strains of recent years. On the other hand, pressure from the European Commission - and from recipients and NGOs - for increased aid budgets in other, today less generous, EU member states will continue. If it will succeed is another matter, and to a large extent depends on the state of the European economy. Therefore, we can expect Nordic exceptionalism in these areas to continue for a foreseeable future. Neither can we expect Europeanisation in the case of aid objectives. Changes in this respect will probably come, but then as the result of global development trends, rather than of EU initiatives. There seems to a bigger chance for a Europeanisation of aid instruments and of co-ordination on the ground. In order to compete with other emerging donors (nota bene, China and India) for influence in the developing world, Lightfoot and Szent-Iványi (2014, p. 14) argue that the EU 'must act in a more concerted and coherent way'. Furthermore, the creation of the European External Action Service will probably lead to renewed and strengthened efforts of EU foreign aid co-ordination in recipient countries. The recent introduction of joint programming in many recipient countries is also gradually involving more countries in field co-ordination (Interviews 3,4). There is, we expect, a willingness in Denmark, Finland and Sweden to comply with such pressures in order to demonstrate their commitment to EU unity and to initiatives to increase the effectiveness of European aid. If this will actually result in real changes in practices and co-operation patterns on the ground depends on the European Union's ability to implement its ambitious plans.

\section{Disclosure statement}

No potential conflict of interest was reported by the authors.

\section{Notes}

1. The fifth Nordic country, Iceland, is an insignificant aid donor and not a member of the EU. Norway is also outside the EU, but is an important donor and has traditionally co-operated closely with the Nordic EU members.

2. As a result, the increased participation of the private sector in development aid is one of the key features of the Busan Global Partnership for Effective Development Cooperation.

\section{References}

Brommesson, D. (2010) Normative Europeanization: The case of Swedish foreign policy reorientation, Cooperation and Conflict, 45(2), pp. 224-244.

Browning, C. (2007) Branding nordicity: Models, identity and the decline of exceptionalism, Cooperation and Conflict, 42(1), pp. 27-51.

Carbone, M. (2007) The European Union and International Development: The Politics of Foreign Aid (London: Routledge).

Carbone, M. (2013) Between EU actorness and aid effectiveness: The logics of EU aid to sub-Saharan Africa, International Relations, 27(3), pp. 341-355. 
De Felice, D. (2015) Europeanisation should meet international constructivism: The Nordic plus group and the internalisation of political conditionality by France and the United Kingdom, European Politics and Society, 17(1). doi: 10.1080/23745118.2015.1075773.

Delputte, S., Lannoo, S., Orbie, J. \& Verschaeve, J. (2015) Europeanisation of aid budgets: Nothing is as it seems, European Politics and Society, 17(1). doi: 10.1080/23745118.2015.1075775.

Delputte, S. \& Orbie, J. (2014) The EU and donor coordination on the ground: Perspectives from Tanzania and Zambia, European Journal of Development Research, 26(5), pp. 676-691.

Development Today. (2010) Farewell to the Nordic aid model, 20th Anniversary Issue of Development Today, XX (21-22).

Elgström, O. (2000) Norm negotiations: The construction of new norms regarding gender and development in EU foreign aid policy, Journal of European Public Policy, 7(3), pp. 457-476.

Falkner, G. \& Treib, O. (2008) Three worlds of compliance or four? The EU15 compared to new member states, JCMS: Journal of Common Market Studies, 46(2), pp. 293-313.

Fejerskov, A. M. (2013) European Union development cooperation in a changing global context, DIIS Report 2013:02 (Copenhagen: Danish Institute for International Studies).

Harman, S. \& Williams, D. (2014) International development in transition, International Affairs, 90(4), pp. $925-941$.

Ingebritsen, C. (2002) Norm entrepreneurs: Scandinavia's role in world politics, Cooperation and Conflict, 37(1), pp. 11-23.

Lawler, P. (1997) Scandinavian exceptionalism and European Union, JCMS: Journal of Common Market Studies, 35(4), pp. 565-594.

Lawler, P. (2007) Janus-faced solidarity: Danish internationalism reconsidered, Cooperation and Conflict, 42(1), pp. 101-126.

Lewis, J. (2005) The Janus face of Brussels: Socialization and every day decision making in the European Union, International Organization, 59(4), pp. 937-971.

Lightfoot, S. \& Szent-Iványi, B. (2014) Reluctant donors? The Europeanization of international development policies in the new member states, JCMS: Journal of Common Market Studies, 52(6), pp. $1257-1272$.

Ministry of Foreign Affairs of Denmark. (2014) The History of Danish Development assistance. Available at http://um.dk/en/danida-en/about-danida/history/ (accessed 29 December 2014).

Ministry of Foreign Affairs of Finland. (2014) Development Policy - Appropriations and Their Use. Available at http://formin.finland.fi/public/default.aspx?contentid=135156\&contentlan=2\&culture= en-US (accessed 29 December 2014).

Naurin, D. (2015) The Councils of the EU: Intergovernmental bargaining in a supranational polity, in: J. Richardson \& S. Mazey (Eds) European Union: Power and Policy-Making, pp. 135-158 (London: Routledge).

Odén, B. (2011) The Africa Policies of Nordic Countries and the Erosion of the Nordic Aid Model. A Comparative Study (Uppsala: Nordiska Afrikainstitutet).

Odén, B. \& Wohlgemuth, K. (2006) Svensk biståndspolitik i ett internationellt perspektiv (Göteborgs universitet: Center for African Studies).

OECD. (2011) Aid Effectiveness 2005-10: Progress in Implementing the Paris Declaration (Paris: OECD). OECD-DAC. (2011) Denmark DAC Peer Review (Paris: OECD/DAC).

OECD-DAC. (2012) Finland DAC Peer Review (Paris: OECD/DAC).

OECD-DAC. (2013a) Sweden DAC Peer Review (Paris: OECD/DAC).

OECD-DAC. (2013b) Norway DAC Peer Review (Paris: OECD/DAC).

OECD-DAC. (2014) Creditor Reporting System (Paris: OECD/DAC). Available at http://stats.oecd.org/ (accessed 29 December 2014).

Olsen, G. R. (2011) Scandinavian Africa policies: Value-based Foreign policies between British affinity, French national interests and EU norms, in: T. Chafer \& G. Cumming (Eds) From Rivalry to Partnership: New Approaches to the Challenges of Africa, pp. 91-105 (Farnham: Ashgate).

Olsen, G. R. (2013) The European Union's Africa policy: The result of Nordicization or Europeanization? Journal of European Integration, 35(4), pp. 409-424.

Orbie, J. \& Carbone, M. (2015) Introduction: The Europeanisation of development policy, European Politics and Society, 17(1). doi:10.1080/23745118.2015.1082688 
Pollack, M. (2009) The new institutionalisms and European Integration, in: A. Wiener \& T. Diez (Eds) European Integration Theories, 2nd ed., pp. 129-41 (Oxford: Oxford University Press).

Pratt, C. (Ed.) (1989) Internationalism Under Strain: The North-South Policies of Canada, the Netherlands, Norway, and Sweden (Toronto: University of Toronto Press).

Rieker, P. (2004) Europeanization of Nordic security: The European Union and the changing security identities of the Nordic States, Cooperation and Conflict, 39(4), pp. 369-392.

Rosamond, B. (2000) Theories of European Integration (Basingstoke: Palgrave Macmillan).

Selbervik, H. with Nygaard, K. (2006) Nordic exceptionalism in development assistance? Aid policies and the major donors: The Nordic countries, Report R2006: 8 (Bergen: Chr. Michelsen Institute).

Stocchetti, M. (2013) Inside the European Consensus on Trade and Development: Analyzing the EU's Normative Power and Policy Coherence for Development in Global Governance, PhD thesis (Helsinki: University of Helsinki).

Stokke, O. (1989) Western Middle Powers and Global Poverty: The Determinants of the Aid Policies of Canada, Denmark, the Netherlands, Norway, and Sweden (Uppsala: Scandinavian Institute of African Studies).

Zemanová, S. (2012) The Europeanization of official development assistance: EU Governance by Cooperation - Communication and domestic change, Eastern Journal of European Studies, 3(1), pp. 31-48.

\section{Interviews}

1. Marina Berg, Head of Section, Coordination of EU Development Policy, European Union Department, Swedish Ministry for Foreign Affairs, 3 July 2014.

2. Ola Sohlström, Seconded Expert from Swedish Ministry for Foreign Affairs, Development Cooperation Coordination Division, European External Action Service, 7 August 2014.

3. Helena Lagerlöf, Section on Coordination of EU Development Policy, European Union Department, Swedish Ministry for Foreign Affairs, 26 September 2014.

4. Maria Sargren, Minister Councellor, Development Policy, Permanent Representation of Sweden to the EU, Brussels, 10 February 2014.

5. Representative of the Embassy of Sweden in Dar-es-Salaam (Tanzania), 26 January 2011.

6. Representative of the Embassy of Denmark in Dar-es-Salaam (Tanzania), 26 January 2011.

7. Representative of the Embassy of Finland in Dar-es-Salaam (Tanzania), 2 March 2012.

8. Representative of the Embassy of Finland in Dar-es-Salaam (Tanzania), 2 March 2012.

9. Representative of the Norwegian Embassy in Dar-es-Salaam (Tanzania), 6 March 2012.

10. Representative of the Embassy of Sweden in Dar-es-Salaam (Tanzania), 2 March 2012.

11. Representative of the Embassy of Sweden in Lusaka (Zambia), 4 February 2011.

12. Representative of the Embassy of Denmark in Lusaka (Zambia), 7 February 2011.

13. Representative of the Embassy of Finland in Lusaka (Zambia), 9 March 2012. 